\title{
RELIGIÃO, TEVÊ E VOTO: A FORÇA POLÍTICA DO CARISMA INSTITUCIONAL IURDIANO
}

\author{
Juliana de Jesus Grigoli ${ }^{1}$ \\ Alessandro Theodoro Cassoli ${ }^{2}$
}

\section{INTRODUÇÃO}

Completando trinta e cinco anos de existência em julho de 2012, o neopentecostalismo faz parte da agenda de debates do meio social brasileiro, tornando-se um tema que percorre as mais variadas esferas e segmentos sociais, sobretudo pela maneira como utilizam os meios de comunicação de massa para ampliar seu quadro de adeptos e garantir a inserção de representantes de seus interesses na esfera política nacional.

Contribuir com a reflexão sobre esses questionamentos é o objetivo desta pesquisa, que consiste na realização de um estudo no campo da teoria social e mídia e que teve como objetivo principal compreender a forma como a Igreja Universal do Reino de Deus (IURD) estabelece parte de suas estratégias de expansão do número de fiéis e de participação direta na esfera política brasileira por meio da aquisição de veículos de comunicação de massa, em especial a televisão.

Tendo em vista esses objetivos, foi realizado, num primeiro momento, leituras de livros, artigos, teses, monografias que abrangem aspectos históricos e conceituais sobre o neopentecostalismo e a Igreja Universal do Reino de Deus. Após esse levantamento teórico, partimos para a investigação documental, com o levantamento de dados disponibilizados pelo Instituto Brasileiro de Geografia e Estatística - IBGE, jornais de ampla circulação nacional, sites e blogs relacionados à temática. Por fim, realizamos um trabalho de campo, no qual acompanhamos a grade de programação da Rede Record de Televisão no dia 20 de fevereiro de 2012 , das $18 \mathrm{~h}$ às $02 \mathrm{~h}$ do dia seguinte, com o intuito de identificar e destacar os pontos de intersecção entre os valores doutrinários difundidos pela IURD e a forma como sua programação está estruturada. A partir desses apontamentos, analisamos como a IURD utiliza

\footnotetext{
${ }^{1}$ Doutoranda no Programa de Pós-Graduação em Sociologia Política da UFSC. Áreas de atuação - Direitos humanos, memória e ditadura civil-militar no Brasil.

${ }^{2}$ Mestrando em Programa de Pós-Graduação em Sociologia Política da UFSC. Área de atuação movimentos sociais.
} 
a televisão como o principal veículo de formação de opinião de massa capaz de conduzir bispos e pastores a cargos políticos de relevância no cenário político.

\section{SURGIMENTO DO NEOPENTECOSTALISMO}

A Igreja Universal do Reino de Deus (IURD) foi fundada em nove de julho de 1977, na Zona Norte da cidade do Rio de Janeiro, pelos pastores Edir Bezerra Macedo e Romildo Ribeiro Soares (conhecido como R. R. Soares). Esse último é casado com a irmã de Macedo, Maria Magdalena Bezerra, e o casal deixa de participar da IURD, tendo fundado a Igreja Internacional da Graça de Deus. A consolidação e expansão da Igreja Universal do Reino de Deus são conduzidas pelo bispo Macedo, reconhecido atualmente como um dos principais propagadores das religiões neopentecostais no mundo. Ainda que seja considerado um fenômeno recente, 0 neopentecostalismo é uma vertente de uma doutrina religiosa que ultrapassa os cem anos - o pentecostalismo. A efervescência do pentecostalismo e do neopentecostalismo no Brasil foi profundamente analisada por Benetti (2004), Silveira (2007), Cassiano (2007) e Dantas (2008), autores em que nos balizamos para compor a síntese será apresentada.

Considerado como uma vertente do protestantismo norte-americano, o pentecostalismo surgiu nos Estados Unidos ainda no início do século XX. Sua liturgia assenta-se no chamado batismo pelo Espírito Santo, segundo o qual esse elemento da Trindade ainda estaria operando milagres pelo mundo, concedendo aos fiéis os chamados dons do Espírito conhecimento e interpretação de línguas celestiais, curas milagrosas, dons de profecia etc. - e sua inspiração bíblica encontra-se na passagem que narra o Dia de Pentecostes ${ }^{3}$, quando teria havido um processo de efusão do Espírito Santo entre os apóstolos e as pessoas que os cercavam, por volta de dois meses após a ascensão de Cristo, como preparação para que cada um dos apóstolos saísse pelo mundo pregando a palavra cristã. O Pentecostes coincidiu com uma tradicional festa judaica em comemoração às colheitas e todos os que dela participavam começaram a falar uma língua estranha, mas ao mesmo tempo perfeitamente compreensível.

Chegando o dia de Pentecostes, estavam todos [apóstolos e povo] reunidos no mesmo lugar. De repente, veio do céu um ruído, como se soprasse um vento impetuoso, e encheu toda a casa onde estavam assentados. ApareceuIhes então uma espécie de línguas de fogo, que se repartiram e repousaram

3 Pentecostes significa quinquagésimo em Grego, e refere-se ao quinquagésimo dia depois da Páscoa, ou seja, depois da ressurreição de Cristo. 
sobre cada um deles. Ficaram todos cheios do Espírito Santo e começaram a falar em outras línguas, conforme o Espírito Santo lhes concedia que falassem. (At 2.1-4).

Desse modo, o ponto central da teologia pentecostal é a crença no "batismo do Espírito Santo", considerado uma experiência reveladora da presença de Deus na vida do indivíduo. Tal manifestação divina pode ser identificada através da glossolalia, fenômeno em que o fiel passa a manifestar-se através de "línguas estranhas" ou em "línguas desconhecidas". De acordo com Mariano (2004), o pentecostalismo distingue-se do protestantismo por defender as práticas do cristianismo primitivo, como a cura de enfermos, o exorcismo do mal e a difusão da crença dos dons do Espírito Santo. Ademais, essa doutrina orienta seus fiéis a manterem uma vida regrada, distante dos hábitos da vida mundana sob a crença de que a vaidade, a luxúria e a ganância são desejos maléficos, ligados ao Diabo.

O movimento pentecostal norte-americano da primeira década do século XX não tardou a se popularizar entre os protestantes para em seguida alcançar várias partes do mundo. No Brasil, o pentecostalismo chega com os primeiros missionários vindos dos Estados Unidos - o ítalo-americano Luigi Francesconi que fundou a Congregação Cristã no Brasil em São Paulo em 1910, e Daniel Berg e Gunnar Vingren que inauguraram, em 1911, o primeiro templo da Igreja Assembleia de Deus, em Belém do Pará.

Durante as décadas de 50 e 60 do século passado, o pentecostalismo de origem norteamericana começa a perder espaço para as primeiras igrejas pentecostais fundadas por brasileiros. Inspirados por essa nova onda doutrinária surgem a Igreja Pentecostal O Brasil para Cristo (IBPC), fundada em 1956 por Manuel de Melo, e a Igreja Pentecostal Deus é o Amor, fundada em 1961 pelo missionário David Martins Miranda. Segundo pesquisa desenvolvida por Cassiano (2007), houve, no mesmo período, a expansão das igrejas pentecostais pela América Latina, com a fundação de novos templos no Paraguai, na Argentina e no Peru.

A partir da década de 50 daquele século, o pentecostalismo passa a experimentar o poder dos meios de comunicação de massa como um dos principais vetores de difusão de sua doutrina, proporcionando acentuada ampliação do número de fiéis. Num primeiro momento, essa difusão ocorreu através das rádios, tendo ganhado força gradativamente dentro da televisão aberta nacional, que rapidamente se tornaria um dos principais veículos de expansão da doutrina.

Por volta de 1980, começam a surgir outras denominações pentecostais (p. ex. Igreja 100\% Vida, Igreja O Brasil para Cristo, etc.) que chamam a atenção da opinião pública pela 
rápida expansão e acúmulo de poder político, econômico e midiático nos últimos trinta anos, caracterizando-se por uma drástica adaptação do discurso tradicional pentecostal à realidade sócio-econômica experimentada pelo Brasil pós-ditadura civil-militar. Assim, essas novas igrejas nascem dentro do movimento que ficou conhecido como neopentecostalismo, também chamado de pentecostalismo autônomo ou pentecostalismo místico por alguns autores. Segundo Mariano (2004), o neopentecostalismo caracteriza-se por:

[...] enfatizar a guerra espiritual contra o Diabo e seus representantes na terra, por pregar a Teologia da Prosperidade [...] e por rejeitar usos e costumes de santidade pentecostais, tradicionais símbolos de conversão e pertencimento ao pentecostalismo (MARIANO apud CASSIANO, 2007, p.11).

Nesse sentido, o neopentecostalismo se diferencia das doutrinas pentecostais mais tradicionais em dois aspectos: nos usos e costumes, ao permitir que seus fiéis se adequem aos padrões estéticos comuns à sociedade contemporânea brasileira; e pela pregação enfática da Teologia da Prosperidade, um tipo de ascese diretamente relacionada à conquista de bens materiais.

Em relação aos usos e costumes, as doutrinas neopentecostais não impedem o uso de maquiagens e não impõem restrições sobre o modo de se vestir, por exemplo, diferentemente do que enfatizam doutrinas pentecostais tradicionais. Sobre a prosperidade, essas igrejas difundem a ideia da legitimidade da busca por uma vida repleta de conforto e abundância, ao contrário das tradicionais, que pregam uma vida de limitações materiais e sacrifícios, como uma forma de respeitar e louvar a Deus. Como reforço a essas afirmações, o neopentecostalismo prega que a pobreza é de origem demoníaca e que o verdadeiro Deus, por ser um pai amoroso e rico, quer ver seus filhos sadios e prósperos. Dessa forma, os fiéis que vivem longe dessa dimensão de riqueza (física, espiritual e material) estariam fora dos propósitos divinos e necessitariam, assim, descobri-los.

De acordo com as considerações de Silveira (2007), esta doutrina é fundamentada em uma teologia que se sintoniza com a realidade vivida pela enorme população pobre e excluída no país, principalmente após o processo de industrialização ocorrido nos anos 1980 e que trouxe como consequência a formação de um contingente de indivíduos desenganados com suas condições de vida, mas que ainda mantinham esperanças de obter melhor qualidade de vida num futuro próximo. Entretanto, engana-se aquele que pensa que o objetivo da doutrina neopentecostal seja apenas oferecer uma resposta esperançosa às inúmeras queixas financeiras de seus fiéis. Por meio da sedutora mensagem Pare de Sofrer, os líderes desse 
segmento afirmam debelar, em nome de Jesus, quaisquer tipos de sofrimento, que vão desde a resolução de problemas relacionados a drogas, alcoolismo e violência dentro da família, passando pela cura de todo tipo de doença (física ou mental), exorcismo de entidades espirituais malignas (o que chamam de encostos) até a resolução de questões mais amenas, como conflitos amorosos, mau-olhado e inveja.

É nesse contexto que se inserem a Igreja Universal do Reino de Deus e a emissora de televisão, a Rede Record, objetos de estudo do presente artigo. Atualmente, parte da programação televisiva da Rede Record - fundada em 1953 e adquirida pela IURD no final da década de 1980 - dedica-se a promover a teologia da prosperidade iurdiana durante as madrugadas, oferecendo apoio emocional e religioso aos espectadores que estejam passando por algum tipo de problema pessoal ou familiar, males que, pela ótica dessa igreja, devem-se diretamente à influência do Diabo.

Assim, o neopentecostalismo passa a ocupar espaços cada vez mais amplos na cultura religiosa no Brasil e na América Latina, fundamentado no discurso da teologia da prosperidade. O crescimento dessa nova vertente cristã muda não só o panorama religioso brasileiro, mas também está operando uma profunda reestruturação do jogo de forças políticas do país, conforme veremos mais adiante.

\subsection{A IDEOLOGIA DA IGREJA UNIVERSAL DO REINO DE DEUS}

Mesmo que o neopentecostalismo seja visto e interpretado como uma espécie de adaptação do pentecostalismo à cultura das sociedades ocidentais e, em grande medida, aos padrões estéticos e de consumo da contemporaneidade, ainda encontramos algumas semelhanças com pentecostalismo tradicional. O mesmo não acontece ao compararmos o neopentecostalismo com o protestantismo histórico. Segundo as considerações de Marcia Benetti (2004), no neopentecostalismo a ética protestante fundamentada no trabalho como uma forma de glorificar a Deus, tal como encontramos em Weber (2004), cede espaço para a magia e o sincretismo.

Assim, diferente daquilo que Weber constatou na obra A Ética Protestante e o 'Espírito' do Capitalismo acerca do desencantamento característico da ascese calvinista, no neopentecostalismo o fiel passa a exigir (ou ao menos tem como certa) a contrapartida prometida por Deus ao povo escolhido (o povo de Israel, ao quais os fiéis da IURD afirmam 
pertencer) em uma série de passagens do Antigo Testamento. Se a ética calvinista desautorizava qualquer questionamento de seus fiéis sobre as intenções divinas para seu destino pessoal, o fiel iurdiano destaca as passagens bíblicas com promessas divinas e tem como certo o cumprimento dessa palavra, desde que assuma e demonstre seu profundo temor a Deus, tendo no pagamento rigoroso do dízimo a principal contrapartida desse pacto. 0 elemento mágico do milagre passa a ser invocado e a IURD faz questão de mostrar depoimentos que comprovam essa tese. Nesse sentido, Cassiano (2007) afirma que, no imaginário iurdiano, Deus está constantemente sujeito a tornar-se refém dos anseios de seus fiéis. Dessa forma, Deus estaria apenas esperando que seus fiéis cumpram suas obrigações, para só então honrar sua parte da promessa e conceder a devida bênção.

Nas palavras do próprio Bispo Macedo,

A pessoa oprimida pela situação financeira precisa [...] aplicar todos os conselhos da palavra de Deus na sua vida, ou seja, seguir fielmente aqueles passos em que Deus promete abençoar-nos financeiramente. [...] É claro que aqueles que são fiéis nos dízimos têm o privilégio de poderem exigir de Deus o cumprimento da Sua promessa em suas vidas e, obrigatoriamente, o senhor tem de cumpri-la (MACEDO apud CASSIANO, 2007, p.13).

Ao analisarmos o discurso de Macedo, percebemos que há uma conexão direta entre magia e sincretismo com a satisfação daqueles que procuram seus templos para realizarem seus desejos mais urgentes. A oferta de bens simbólicos revestida de uma aura sobrenatural é um dos recursos mais utilizados pela IURD tanto nos cultos realizados nos templos quanto na programação transmitida pela Rede Record. Nessas ocasiões, os pastores utilizam certos tipos de artifícios mágicos e sincréticos como parte de seus argumentos, como, por exemplo, o 'manto da riqueza', o 'óleo ungido', a 'água abençoada' e a 'areia do deserto de Sinai'.

Em nosso caso empírico, constatamos esse mesmo componente mágico, encarnado pelo herói bíblico Davi, guerreiro invencível uma vez que fora ungido pelo deus de Israel. Davi parece ser o arquétipo a ser perseguido pelos fiéis iurdianos, ponto em torno do qual toda a liturgia neopentecostal é estruturada. Ao contrário do católico, cuja meta é trilhar o mesmo caminho de Jesus Cristo (não reagir à violência, perdoar seus inimigos, dar a outra face etc.), o fiel iurdiano é chamado a seguir o exemplo do guerreiro Davi, acreditando nos poderes sobrenaturais a ele conferidos a partir da unção divina e, assim, instado a encarar a luta contra o mal com a espada na mão. Da mesma forma, essa mística é transferida para o campo da 
política, nesse caso substituindo a espada de Davi pelo ato do voto nos candidatos apoiados pela IURD, como veremos mais adiante.

É através desse maniqueísmo, apoiado por uma sofisticada estratégia que tem a tevê como seu principal canal de difusão, que a IURD expande seu número de fiéis. O fiel, uma vez ungido por Deus, ganharia o poder de escapar - de forma absolutamente mágica - da figura onipresente do demônio.

Basicamente, são três os pilares que sustentam a fé propagada pelos pastores iurdianos: a salvação, a cura e a prosperidade. Dessa forma, o mal, representado pela figura do Diabo, é essencial para a Igreja Universal, já que "sem a existência de uma entidade maligna não haveria uma razão aparente para desejar salvar-se" (CASSIANO, 2007, p.15). Assim, "salvação e felicidade misturam-se, como se unem também espiritualidade e materialidade" (BENETTI apud CASSIANO, 2007, p.15).

Em relação ao significado de salvação, Macedo, ao trazê-la para uma dimensão palpável e rejeitar as ideologias cristãs mais tradicionais em nome do pragmatismo, passa a traduzi-la como cura e prosperidade, o que fica claro quando afirma que "todas as formas e todos os ramos da Teologia são fúteis". Ao relacionar espiritualidade e materialidade, a IURD utiliza uma estratégia discursiva bem formulada, centrada na ideia de que "tudo tem seu preço, se o objetivo que eu quero alcançar é muito alto, então alto também será o preço do sacrifício que teria que pagar" (id ibid.). Tem-se aqui a origem da justificativa para o compromisso do fiel com o dízimo - sua contrapartida no pacto pessoal firmado com Deus.

\subsection{MASSA, RELIGIÃO, POLÍTICA E TEVÊ}

Com o claro objetivo de expandir o número de fiéis e consolidar a IURD como grande representante do neopentecostalismo nacional, Edir Macedo, que já utilizava o rádio como veículo de difusão de sua doutrina, incorpora, em 1989, uma estratégia que aceleraria a expansão de seu poder religioso. Naquele ano, com a compra da Rede Record de Televisão, por 45 milhões de dólares, a IURD concretiza a migração para o mais poderoso dos veículos de comunicação de massa.

Sem entrar na polêmica sobre o valor pago pela IURD para a aquisição da emissora, bem como da origem dos recursos econômicos que mantém seus negócios, assunto exaustivamente tratado por Cassiano (2007), nossas atenções se voltam para uma análise da TV como veículo de comunicação estratégico para a formação de uma massa religiosa que 
possibilitou, dentre outras coisas, a inserção de representantes do alto clero da IURD no cenário político brasileiro.

Nesse sentido, se a relação do homem com a arte sofreu profundas transformações a partir da criação de ferramentas capazes de replicá-la indefinidamente, como mostrou Walter Benjamin (1969), podemos tentar compreender como a relação entre homem e religião tem se transformado com o processo de midiatização do culto religioso. Para Benjamin, as formas de fruição estética das mais diversas criações artísticas - música, pintura, teatro etc. - teriam perdido a dimensão da unicidade espaço-temporal: um concerto é registrado por meio de ferramentas tecnológicas e logo em seguida pode ser replicado e difundido numa escala virtualmente ilimitada, nos mais variados locais e tempos. A reprodutibilidade técnica supera, assim, as limitações espaço-temporais antes intrínsecas ao produto artístico humano. No entanto, tal processo destrói o que o autor chamou de aura de sacralidade da obra de arte, aquilo que a torna única e por isso mesmo arte, ou seja, destrói sua unicidade. A ocorrência única transforma-se em ocorrência em massa - continua o autor - e esse processo não é exclusivo do campo artístico ${ }^{4}$. A tradição do objeto artístico original perde força no moderno processo de transmissão cultural; em outras palavras, o objeto perde seu valor de culto.

A IURD não canoniza objetos sacros, como faz o catolicismo. É iconoclasta, entretanto cria constantemente rituais e objetos mágicos, amuletos para atrair prosperidade. Não cria nada para ser cultuado, porém reifica aquela divindade que o Novo Testamento havia silenciado. É em nome dessa divindade que a IURD conclama e conduz sua massa, por meio de um conjunto de significados simbolicamente tratados nos mitos, nos sonhos, nos ritos e no discurso. A magia e os símbolos são considerados - como nos mostra Canetti (1995) - aspectos fundamentais para a formação e a expansão contínua da massa, já que tais elementos produzem os sentidos que garantem a coesão e a unidade de determinada massa. Assim, o sobrenatural, materializado em objetos como o 'manto da riqueza', o 'óleo ungido', a 'areia do deserto do Sinai' etc. - exemplos da simbologia mágica criada constantemente pela IURD operam no imaginário coletivo, trazendo sensações de unidade e pertencimento a partir da contemplação de seus símbolos como "uma luz natural", dotada de poder divino.

Desse modo, a massa iurdiana apresenta múltiplos contornos. Ao analisarmos suas

\footnotetext{
${ }^{4}$ BENJAMIN, Walter. A obra de arte na época de sua reprodutibilidade técnica. In: GRÜNNEWALD, José Lino. A Idéia do Cinema. Rio de Janeiro: Civilização Brasileira, 1969.
} 
diversas camadas, percebemos a existência de um núcleo cristalino, coeso, tal como aquele concebido por Canetti (ibid., p.74-75), isto é, um núcleo formado por bispos e pastores, responsável pela durabilidade do segmento ao qual pertencem por meio do estabelecimento dos valores e da simbologia que conduzem a fé iurdiana. Mesmo quando aparecem individualmente, esses representantes transmitem a solidez desse segmento religioso dando sentido e unidade à massa de fiéis por eles conduzida. Fora do núcleo, a massa é composta, em sua maioria, por indivíduos egressos de uma situação anômica ${ }^{5}$ e que se dispuseram, no limite, a passar por um processo de reciclagem, de reinserção social através da recuperação de sua capacidade de consumo intrínseca à cultura das sociedades contemporâneas ocidentais. A massa iurdiana é arregimentada junto àquela parcela da população que se encontra desesperada e aflita, ao enxergar-se dentro de uma máquina social que lhe extrai toda força de trabalho e muito pouco lhe dá em troca.

Uma das estratégias utilizadas por Macedo para garantir a expansão da massa iurdiana, especialmente durante o período em que foi acusado de manipulação indevida dos recursos por ele administrados, foi o de explorar o sentimento de perseguição religiosa, com a nomeação de inimigos no próprio campo midiático. Em 1995, a divulgação de um vídeo no Jornal Nacional mostrou Edir Macedo contando dinheiro arrecadado com o dízimo e ofertas num templo em Nova York, divertindo-se em um iate e instruindo pastores a arrecadarem mais doações junto aos fiéis. Isso foi interpretado como um ataque à ideologia religiosa iurdiana, visando abalar a massa com o propósito de destruí-la. Essa estratégia da Rede Globo resultou num contra-ataque imediato da IURD, que resultou no fortalecimento da massa iurdiana. Curiosamente, o que Canetti explica é que o ataque ou a simulação de um ataque exterior à massa só faz fortalecê-la, pois promove uma aproximação dos corpos unitários que a constituem, resultando na consolidação de uma identidade propriamente dita.

Tendo em vista a expansão da massa de forma ilimitada, tratando-a como uma massa sempre aberta, há uma segunda etapa de constituição da massa iurdiana, que passa pela domesticação de seu modo de agir e de pensar, já que toda massa necessita de um ritmo e de uma direção. De acordo com Canetti, toda massa está em constante movimento e a direção

\footnotetext{
5 Termo empregado aqui tal como foi definido por Durkheim. Anomia seria um estado de falta de objetivos e perda de identidade, provocado pelas intensas transformações ocorrentes no mundo social moderno, individualista e extremamente competitivo. (DURKHEIM, 2012).
} 
comum a todos os seus membros fortalece o sentimento de igualdade, já que "a direção é imprescindível para sua durabilidade" (ibid, p.28).

Nesse sentido, a Rede Record desempenha uma função de certo modo ambivalente. Ao mesmo tempo em que ela atua como um canal de expansão da massa cumpre também a função de dar coesão à massa de fiéis já existente por meio de uma programação reforçadora do discurso maniqueísta que privilegia a difusão de valores inerentes à doutrina e à moralidade iurdiana, discurso este assentado ora na luta do bem contra o mal, ora na dualidade sofrimento e prosperidade. Dessa forma, o problema da desagregação da massa é contornado utilizandose mais uma vez a dualidade entre Deus e o Diabo, já que no campo terreno não existiria território neutro. Cada indivíduo poderia estar somente de um desses lados. Quem porventura saísse da massa religiosa em questão, passaria invariavelmente para o outro lado, regido pelo mal. Dessa forma, a TV passa a atuar no cotidiano de seus telespectadores como um veículo que dita um determinado ritmo e estabelece zonas de obscuridade e de tensão, seja pelo medo ou pelas metas iurdianas que abrangem desde atitudes individuais até escolhas que passam pelo campo da coletividade, da política à economia. Como veremos abaixo, ou se está do lado de Davi - o eleito entre o povo de Deus -, ou do lado de Golias - o quasímodo filisteu.

\section{A TEVÊ COMO CAMPO DE BATALHA}

Na noite de 20 de fevereiro de 2012 - segunda-feira de carnaval -, as redes de tevê Globo e Record ocuparam dois terrenos completamente distintos na disputa por audiência. De um lado, o tradicional veículo da oligarquia eletrônica vendendo um de seus principais produtos culturais; de outro, o emergente porta-voz da moralidade cristã pós-calvinista, relembrando as virtudes perdidas dos patriarcas bíblicos. Dois canais de tevê, cada qual encastelado em seu território ideológico, disputam a atenção dos telespectadores que não foram rezar nem sambar naquela noite. Como mediador desse combate, o Instituto Brasileiro de Opinião Pública e Estatística (Ibope), livre para atribuir o score político de cada canal a partir do número estimado de cabeças conectadas em cada um deles.

Arbitramos começar a reconstruir esse cenário de disputa a partir das dezoito horas, quando Record e Globo disputavam a audiência jovem com as mesmas armas: novelas teen cujos enredos, dada a similitude, pareciam ter sido gerados pelo versificador sonhado por Orwell, na Oceania de 1984. 
Dez para as oito começa o jornal regional da Record, o RIC Notícias, com a cobertura do carnaval estadual, intercalado por matérias sobre os efeitos negativos da folia em todo o país: violência, assaltos e o descaso dos foliões com as regras sociais. O gari ganha voz e reclama do costumeiro aumento de trabalho no período. O custo social do carnaval é a mensagem que permeia todo aquele horário jornalístico. Já na Rede Globo o foco é a folia, a alegria dos foliões, o carnaval enquanto expressão última de uma brasilidade festeira. O vai-e-vem entre os canais revela uma mudança da tônica daquilo que parecia o mesmo, no momento das novelas juvenis. Ao final de cada bloco do Jornal da Record, Ana Paula Padrão e Celso Freitas - exestrelas do jornalismo global - se revezavam na função de anunciar a mudança de programação da Rede Record, que decidira substituir a cobertura do carnaval pela transmissão de um "compacto" da minissérie Rei Davi, superprodução da emissora que estava sendo exibida havia alguns dias, de orçamento milionário e repleto de estrelas egressas do Projac.

Enquanto isso a Globo apresentava a cobertura ao vivo da concentração do sambódromo do Rio. Às vinte e uma horas, inicia o desfile das escolas cariocas na Rede Globo, enquanto que a Rede Record inicia a transmissão de sua novela Vidas em Jogo, composta por diálogos e cenas com intenso conteúdo moral cristão.

O carnaval da Globo estava em pleno vapor quando, às vinte e duas horas, começa o compacto do Rei Davi, no qual o humilde pastor de ovelhas bíblico era ungido pelo profeta Samuel como herdeiro do trono de Israel. O samba-enredo global passava agora a competir com um enredo apócrifo de 600 a.C. livro primeiro de Samuel, capítulos 16 ao 31, adaptado pela ex-redatora da emissora, Vivian de Oliveira. O tabuleiro midiático permaneceria dividido entre sagrado e profano das vinte e duas horas até a uma da madrugada. No dia seguinte, a comunidade gospel comemorava aquilo que chamou de vitória da virtude ${ }^{6}$. Davi derrotara dois gigantes: Golias, com um tiro de funda, e a Globo, por doze pontos a dez no Ibope, o que significa que seiscentos e noventa mil lares da Grande São Paulo preferiram acompanhar as peripécias do sucessor do rei Saul, cento e dezesseis mil televisores a mais do que o total conectado na rival carnavalesca.

Esse feito constituiu vitória histórica na tevê aberta brasileira, já que o carnaval é um dos principais produtos midiáticos da Rede Globo, tradicional campeã de audiência nesse período do ano. A vitória da Rede Record nesse episódio causou surpresa e virou notícia nos

6 Fonte: Inforgospel - odiario.com. Acesso no dia 14/03/2012. 
principais veículos do país. A tradição do desfile carnavalesco, enquanto manifestação artística até então alardeada como uma das mais evidentes manifestações de brasilidade começa a demonstrar enfraquecimento frente a novas alternativas de recreação televisiva. De alguma forma, o sagrado promove certa profanação do profano, até então hegemônico no imaginário da cultura nacional.

\section{O PREÇO DO PRESIDENCIALISMO DE COALIZÃO}

Um fato que optamos por analisar fora do território da simples coincidência foi a indicação do bispo licenciado da IURD e senador pelo PRB (Partido Republicano Brasileiro) do Rio de Janeiro, Marcelo Crivella, para assumir o Ministério da Pesca, apenas nove dias depois da dupla vitória no terreno midiático e religioso de Davi e da Record. Antiga sigla do vice de Lula, José Alencar (1931-2011), o PRB agrega boa parte do episcopado da IURD, compondo aliança estratégica com o PT (Partido dos Trabalhadores). No entanto, a entrada de Crivella não significou um ministério a mais para a legenda da presidenta, pois a pasta era ocupada até então pelo deputado federal Luiz Sérgio, do PT do Rio de Janeiro. O PRB conta no momento com doze deputados federais, incluindo o boxeador Acelino Popó, representando a Bahia, além de vinte e três deputados estaduais, cinquenta e dois prefeitos e setecentos e setenta e oito vereadores ${ }^{7}$. Conforme noticiado, “Crivella é apontado como uma indicação estratégica para aproximar o governo do setor evangélico" ${ }^{8}$ visando apoio para a eleição de Fernando Haddad (PT-SP) para a prefeitura de São Paulo.

Essa estratégia é facilmente compreensível quando analisamos os dados censitários nacionais. De acordo com o censo 2000 do $\mathrm{IBGE}^{9}$, os católicos representam $73,6 \%$ da população nacional, evangélicos $15,4 \%$ e pentecostais $10,4 \%$. Na cidade de São Paulo, as cifras passam para $68,1 \%, 15,9 \%$ e $11,5 \%$, respectivamente.

Assim, no dia dois de março desse ano, Dilma destitui - aos prantos - o companheiro de partido e entrega a pasta da Pesca ao bispo Crivella, que faz uma oração pedindo bons fluidos por parte daquele mesmo deus que ajudou Davi. Para se ter uma ideia da dimensão que o fato teve dentro no núcleo iurdiano, a programação da Record News foi interrompida

7 Fonte: www.prb.orb.br. Acesso no dia 14/03/2012.

8 http://www.jb.com.br/pais/noticias/2012/03/02/na-posse-de-crivella-dilma-chora-e-defende-politicade-coalizao/, acesso em 14/03/2012.

9 IBGE, censo 2000, Tabela 2094 - População residente por cor ou raça e religião (dados do censo 2010 ainda não disponíveis). 
para transmitir ao vivo a posse do novo ministro. Em nome do presidencialismo de coalizão, o PT entregou a tutela dos peixes - símbolo do cristianismo - ao senador, bispo, cantor e escritor da IURD.

A ascensão de Crivella ao Ministério da Pesca não pode ser interpretada como consequência pura e simples da vitória iurdiana na tevê, dias antes. Mais do que isso, a nomeação do bispo coroa uma estratégia política adotada pelas lideranças da IURD em 1986, quando a igreja conseguiu eleger um representante para a Assembleia Constituinte. Como aponta Oro (2003, p.99-103), a articulação política da Universal começa na década de 1980 em torno do PL (Partido Liberal) e registra rápido crescimento do número de representantes no Congresso, fenômeno que acompanha a tendência de crescimento do carisma político pentecostal, passando de três deputados federais em 1990 para vinte e dois em 2002, o que representa cerca de um terço dos parlamentares da bancada evangélica daquele mandato. Oro resgata o conceito de carisma institucional de Weber para explicar a eficácia política da IURD (ibid, p.100-102). Os fiéis são conclamados a votar em seus irmãos de fé - todos eles pastores escolhidos pela direção da igreja - para que 'o povo de Deus' seja representado nas instâncias políticas do país. $\mathrm{O}$ ato de votar ganha conotação de uma espécie de guerra santa; o diabo estaria instalado no Congresso Nacional, nas palavras do ex-articulador político da IURD, Bispo Rodrigues (ibid, p.106). Como o autor salienta,

Evidentemente que o exitoso exercício da autoridade carismática iurdiana na política não se dá de forma opressiva. A sua legitimação ocorre mediante a mobilização de vários elementos práticos e simbólicos. Ou seja, por um lado, a IURD faz uso da sua bem montada rede midiática, impressa, eletrônica e assistencialista. E, por outro lado, também traz para o campo político e para a construção da sua representação política, elementos doutrinários e discursivos presentes em sua cosmovisão religiosa, reproduzindo, assim, um procedimento comum aos evangélicos de 'religiogizar' o político. (ORO, 2003, p.104)

O caráter institucional do carisma iurdiano fica mais evidente quando se compara a performance de candidatos que haviam contado com o apoio da igreja para a eleição em suas primeiras candidaturas, e assim obtido expressivo número de votos, com a esmagadora derrota por eles experimentada após racharem com a direção da igreja e lançarem candidatura independente para um possível segundo mandato. Conforme destaca Oro (2003), o apoio oficial da igreja é determinante para o sucesso eleitoral dos candidatos. Uma vez retirado o apoio, a figura individual do político perde completamente sua força, já que os veículos midiáticos da IURD passam a transmitir notas oficiais da direção da igreja denunciando 
candidatos que estariam usando indevidamente o nome da instituição em suas campanhas. É a direção da igreja que determina quem serão seus candidatos oficiais, não antes de realizar uma espécie de censo eleitoral entre seus fiéis e contrapor esses dados aos coeficientes eleitorais para cada região. A partir desses dados, é definido o número de candidatos para cada cargo e região, e seus nomes passarão a ser divulgados nas respectivas igrejas. Painéis informativos e urnas eletrônicas são usados para instruir os fiéis, durante os cultos e demais encontros, sobre como efetivar seus votos para esses candidatos. Dessa forma, o fiel da Universal é estimulado a ver no voto uma poderosa ferramenta para combater as forças satânicas que estariam operando na política, origem de toda a corrupção registrada no meio. Cabe ressaltar que os parlamentares da IURD dificilmente se envolvem em casos de corrupção, diferentemente do que acontece com demais parlamentares de outras confissões que compõem a chamada bancada evangélica, o que reforça ainda mais o discurso do combate à diabolização do meio político.

\section{CONSIDERAÇÕES FINAIS}

O presente trabalho nos colocou diante de desafios que não imaginávamos quando elegemos essa temática de pesquisa. A contextualização histórica sobre o neopentecostalismo revelou, aos poucos, complexas conexões entre personagens políticas e religiosas que evidenciam uma importante movimentação no cenário político brasileiro, em especial o surgimento de novas configurações e coligações entre partidos políticos, empresários de diversos segmentos e interesses que resultaram em um reordenamento das forças políticas nacionais. No campo ideológico a complexidade parece ser ainda maior, dada a natureza difusa intrínseca a essa dimensão da vida social, o que torna invisível a fronteira que separa a ideologia iurdiana das demais ideologias neopentecostais.

Reconhecemos a natureza fundamentalmente descritiva do estudo ora apresentado, porém não tivemos como deixar de dar destaque aos pontos que consideramos fundamentais para uma introdução que se pretenda consistente para a realização de estudos que tratem dessa temática. Ao procurar mesclar análises sobre os três campos que alinhamos ao longo dessa pesquisa, quais sejam, massa religiosa, política e mídia, constatamos a dificuldade de encontrar autores que abordassem essas temáticas de forma conjunta. Em contrapartida, encontramos em Canetti argumentos que permitiram a proposição de uma análise que cruzasse os conceitos de massa e religião e em Walter Benjamin os elementos teóricos que 
permitiram traçar um esboço - a partir do paralelo traçado com a arte - da transformação da ação religiosa operada pelas modernas formas de reprodução técnica do discurso religioso.

Se não logramos encontrar um marco teórico capaz de correlacionar com maior clareza os três campos sobre os quais nos debruçamos, esperamos ao menos ter delineado um esboço do caminho a ser percorrido para compor uma análise sociológica mais consistente que pretenda correlacionar o comportamento da massa religiosa neopentecostal, seu discurso midiático e os desdobramentos políticos decorrentes dessa novíssima práxis religiosa, cujos efeitos já tardam a serem debatidos no meio científico nacional.

\section{REFERÊNCIAS}

BENETTI, Marcia. Deus vence o diabo: o discurso de testemunhos da Igreja Universal do Reino de Deus. Tese (Doutorado em Comunicação e Semiótica). São Paulo: PUC, 2000.

- Sagração e consagração do sujeito: a televisão confere existência aos "escolhidos" da Igreja Universal do Reino de Deus. In: Comunicação e práticas culturais. Porto Alegre: UFRGS, 2004.

BENJAMIN, Walter. A obra de arte na época de sua reprodutibilidade técnica. In: GRÜNNEWALD, José Lino. A Idéia do Cinema. Rio de Janeiro: Civilização Brasileira, 1969.

BÍBLIA SAGRADA, Português. Atos dos Apóstolos. SP: Edição Claretiana, 2005.

CANETTI, Elias. Massa e poder. São Paulo, Companhia das Letras: 1995.

CASSIANO, Bruno. Religião e Jornalismo: uma analise das matérias de capa do jornal Folha Universal. Monografia (Comunicação Social). Rio Grande do Sul: UFRGS, 2007.

DANTAS, José Gibson. O comportamento dos telespectadores diante da programação televisiva da neopentecostal. In: Protestantismo em Revista, volume 16, 2008.

DURKHEIM, E. O Suicídio. São Paulo: Martin Claret, 2012. 
MARIANO, Ricardo. Expansão pentecostal no Brasil: o caso da Igreja Universal. In: Estudos avançados, v.18, n.52. SP: USP, 2004.

ORO, Ari Pedro. Organização eclesial e eficácia política: o caso da Igreja Universal do Reino de Deus. Civitas: Revista de Ciências Sociais, v.3, no1, pp.97-109. Porto Alegre: PUC-RS 2003.

SILVEIRA, Marcelo. O discurso da Teologia da Prosperidade em Igrejas Evangélicas Pentecostais: estudo da retórica e da argumentação do culto. Tese (Doutorado em Filologia e Língua Portuguesa). SP: USP, 2007.

WEBER, Max. A Ética Protestante e o Espírito do Capitalismo. SP: Cia.das Letras, 2004.

\section{OUTRAS FONTES CONSULTADAS}

G1.Senador Marcelo Crivella Assume Ministério da Pesca e anuncia planalto.Disponível em: < http://g1.globo.com/politica/noticia/2012/02/senador-marcelo-crivella-assume-ministerioda-pesca-anuncia-planalto.html>. Acesso em 14 mar. 2012.

IBGE. < www.ibge.gov.br>. Acesso em 14 mar. 2012.

Inforgospel - O Diário.com. "Rei Davi" Minisserie fica no ibope à frente do carnaval em SP. Disponível em:

<http://www.odiario.com/blogs/inforgospel/2012/02/21/rei-davi-minisserie-fica-no-ibope-nafrente-do-carnaval-da-globo-confira/.> Acesso em 14 mar. 2012.

Jornal do Brasil. Na posse de Crivella Dilma chora e defende política de coalizão. Disponível em:- <http://www.jb.com.br/pais/noticias/2012/03/02/na-posse-de-crivella-dilma-chora-edefende-politica-de-coalizao/>

Acesso em 14 mar. 2012.

Patiogospel. Record transmite posse de Marcelo Crivella no Ministério da Pesca. Disponível em: <http://www.patiogospel.com.br/2012/03/record-transmite-posse-de-marcelo.html> Acesso em 14 mar. 2012.

Partido Republicano Brasileiro. < www.prb.orb.br> Acesso em 14 mar. 2012. 


\section{RESUMO}

Analisar a força do carisma político neopentecostal, amplificado e difundido por uma estruturada rede de comunicação que começa a tomar contornos internacionais, é o principal objetivo do presente estudo. Para tanto, tomaremos como objeto de análise a Igreja Universal do Reino de Deus e seu principal veículo de comunicação, a Rede Record de Televisão. Na primeira parte do artigo apresentaremos um histórico sobre o fenômeno religioso neopentecostal. Em seguida, descreveremos um caso emblemático atual que permite correlacionar, em termos sociológicos, religião, mídia e política. E na terceira parte buscaremos trazer elementos teóricos dessas três áreas temáticas para fundamentar as problematizações que sistematizadas tendo como fundamento os argumentos e conceitos de Elias Canetti (1995) sobre massa e massa religiosa.

PALAVRAS-CHAVE: neopentecostalismo; mídia; política.

\section{ABSTRACT}

Analyze the strength of political charisma neopentecostalism, amplified and broadcast by structured communication network that begins to take shape international, is the main objective of this study. To this end, we will take as the object of the analysis the Universal Church of the Kingdom of God and his main vehicle of communication, the Rede Record TV. In the first part of the paper we present a history of the neopentecostalism religious phenomenon. Then, we describe a typical case now to correlate, in sociological terms religion, media and politics. And the third part will try to bring theoretical elements of these three thematic areas to substantiate that problematizations systematized taking as a basis the arguments and concepts of Elias Canetti (1995) mass and mass religious.

KEYWORDS: neopentecostalism; media; politics.

Recebido para publicação em: 23/05/2012

Aceito em: 05/11/2012 